Article

\title{
An Analysis of the Causes of Deforestation in Malawi: A Case of Mwazisi
}

\author{
Susan Ngwira ${ }^{1, *}$ and Teiji Watanabe ${ }^{2, *(\mathbb{D})}$ \\ 1 Graduate School of Environmental Science, Hokkaido University, Sapporo, Hokkaido 060-0810, Japan \\ 2 Faculty of Environmental Earth Science, Hokkaido University, Sapporo, Hokkaido 060-0810, Japan \\ * Correspondence: susanngwira1@gmail.com (S.N.); teiwata@mac.com (T.W.)
}

Received: 4 February 2019; Accepted: 11 March 2019; Published: 15 March 2019

\begin{abstract}
Deforestation is recognized as a major driver of the loss of biodiversity and ecosystem services. It also disturbs natural processes such as biogeochemical, hydrological, and ecological cycles. In Malawi, deforestation is estimated to be responsible for the loss of 33,000 hectares per year, and is mainly attributed to agriculture expansion, tobacco growing, and excessive use of biomass. However, little research has been conducted at either the local level or that of forests located on customary land. This research aimed to identify and analyze the underlying driving factors associated with the proximate factors of agriculture expansion, tobacco growing, and brick burning in Mwazisi. Landsat images for 1991, 2004, and 2017 were downloaded from the United States Geological Survey website and used to analyze changes in forest cover. Interviews with households $(n=399)$ and Natural Resource Committee members, a focus group discussion with key officers, and observations were conducted during field data collection in 2017. The results of the land cover analysis showed that forest covered $66 \%$ of the study area in 1991, and by 2017 it had decreased to $45.8 \%$. Most households depend on wood from customary land forests for tobacco curing $(69 \%)$ and brick burning (68\%). Furthermore, $47.6 \%$ of the households have expanded their agriculture land by approximately 0.57 hectares during the past 15 years. The interview survey and the focus group discussion identified that the underlying driving factors towards these anthropogenic activities are: (a) population growth, (b) poverty, (c) expensive alternative building materials, (d) lack of awareness, (e) lack of resources, (f) lack of commitment from the tobacco companies, and (g) market system of the cash crops grown in the area. In conclusion, a set of economic, institutional, social, and demographic factors, which are associated with imbalanced relationship between rural and urban areas, underpin agriculture expansion, tobacco growing, and brick burning, and have thereby contributed to the decline of the forest cover in Mwazisi, Malawi.
\end{abstract}

Keywords: underlying factors; proximate factors; socioeconomic survey; forest change; local level

\section{Introduction}

Deforestation is known as one of the most important elements for changes in land use and land cover. It is recognized as a major driver of the loss of biodiversity and ecosystem services. Globally, it has been occurring at an alarming rate of 13 million hectares per year [1]. It is believed that high population growth coupled with the rapid expansion of agriculture is responsible for the accelerated rates of deforestation, especially in developing countries [2].

Malawi is a developing country in which enormous pressure is being exerted on forest resources. Forest cover of the country reduced from $47 \%$ in 1975 to $36 \%$ in 2005 [3]. This is the highest deforestation rate in the Southern African Development Community (SADC) region, representing a net loss of some 30,000 to 40,000 hectares per year [3]. This forest loss is mainly attributed to agriculture expansion and excessive use of biomass, such as wood, charcoal, and agricultural residues mostly used for cooking 
and heating [4]. That is, biomass accounts for $88.5 \%$ of the country's energy demand, $6.4 \%$ comes from petroleum, $2.8 \%$ from electricity (hydro power), and $2.4 \%$ from coal $[5,6]$.

Agriculture is a source of livelihood for more than $90 \%$ of the rural and urban population and represents more than three quarters of national exports [7]. The expansion of subsistence agriculture to meet the food needs of the burgeoning population has been one of the main causes of deforestation in Malawi $[8,9]$. While $62 \%$ of the land was agriculture in 1991 , by 2008 , the agriculture land had reached $70 \%$ [10]. In commercial farming, tobacco is one of the major export crops and accounts for approximately $67 \%$ of the export earnings from agriculture in Malawi [11,12]. However, the percentage of deforestation caused by tobacco farming is very high—it reached $26 \%$ by the early 2000 s [13]. Tobacco is further ranked as the highest user of wood among non-household users in Malawi. It involves the use of wood and twigs in construction of barns for air-cured tobacco and firewood for fuel-cured tobacco. The construction industry is also heavily reliant on wood energy for brick production and is ranked second from tobacco in this regard. The brick-making industry alone consumes approximately 850,000 metric tons of wood per year $[14,15]$. That is, biomass in the form of wood fuel is the largest form of primary energy consumed in Malawi. Malawi obtains $88 \%$ of its total energy and $98 \%$ of its household energy from traditional biomass, while access to modern energy is less than $10 \%[15,16]$. Inefficient production and unsustainable use of biomass energy have contributed to environmental degradation, such as high deforestation, desertification, and soil erosion $[5,6]$.

There are three land categories in Malawi: public land, private land, and customary land. Public land is the land held in trust for the people of Malawi and managed by the government [17]. Private land is the land that is registered as private under the Registered Land Act [17]. Customary land is the land used for the benefit of the community as a whole within the boundaries of a traditional management area (Land Act 2016). Customary land is held or used by community members under customary law and is under the jurisdiction of the customary traditional authorities [18]. The customary land makes up around $85 \%$ of the total land in Malawi [19]. Forest resources on customary land are usually most accessible to the majority of the rural residents (for example, [20]), and are also very important because they provide not only timbers/fuel wood but non-timber forest products for both rural and urban population. Although previous studies and projects have provided a fundamental understanding regarding the protection of forests and forests' contribution to rural development [21-23], achieving a reduction in deforestation requires an understanding of how local people utilize and manage forest resources. That is, their behavior and impact on the forests differ substantially, despite the fact that each local community operates under the same national legislation [24]. Local-level data provide rich information on how people at the local level interact with forest resources. Conversely, country-level data on the rates of deforestation do little to help policymakers and scholars unravel the web comprising the causes of forest loss $[24,25]$. Deforestation rates vary significantly within each country, and furthermore, an understanding of the causes of such dynamics and unique variation within the country is critical for the establishment of proper interventions.

Several studies on agriculture expansion, benefits and tradeoffs of tobacco, land tenure, biomass use, population, and poverty, and their impacts on forest resources have been conducted in Malawi (for example, [26-28]). However, only a few studies have been conducted at the local level about the drivers of deforestation, especially on customary forest land [22,29].

There are some anthropogenic proximate factors or causes of deforestation, which are human activities or immediate actions such as agriculture expansion that directly impact forest cover [30]. In the case of Malawi, agriculture expansion, tobacco growing, and brick production are regarded as the major proximate factors of deforestation. Underlying driving factors or forces are fundamental social processes such as population dynamics that underpin the proximate causes [30]. Classification of the underlying driving factors varies from area to area as that of the proximate factors do [30-32]. Deforestation has been discussed in a research framework of land science with the focus on the proximate factors and underlying driving factors (for example, [33-35]); however, there are no studies 
using such a research framework in Malawi. This study, adopting this research framework, aims to identify and analyze forest cover change and the underlying driving factors associated with the proximate factors of deforestation on customary land in the rural area of Mwazisi, Malawi (Figure 1), where no research about the drivers of deforestation has been conducted to date.
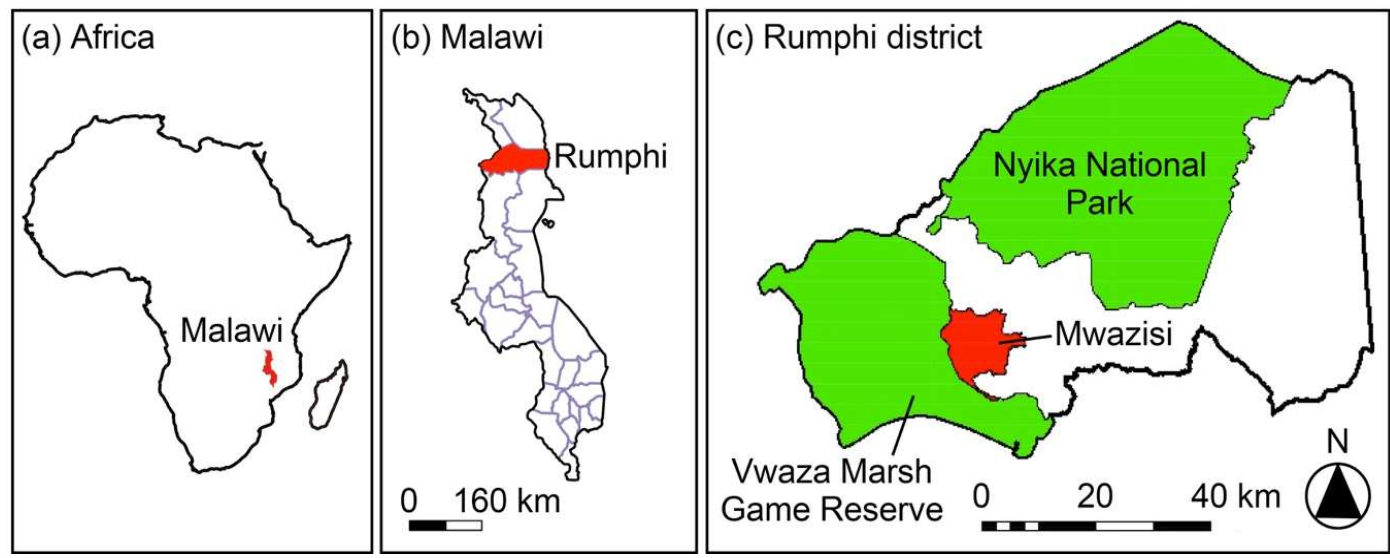

Figure 1. Location of the study area.

\section{Materials and Methods}

\subsection{Study Area}

The Mwazisi zone, which is the customary land, is located to the west of the Rumphi district in the northern region of Malawi. It consists of six Village Development Committees (VDCs) under the Traditional Authority Chikulamayembe. Traditional Authority is a form of leadership in which the authority of an organization or a ruling regime is largely tied to tradition or custom. The Mwazisi zone is located along Vwaza Marsh Game Reserve (VMGR) and covers an area of $117 \mathrm{~km}^{2}$, which contains 1126 households. The total population of the study area is estimated to be approximately 6570 . The area is mostly covered by Miombo woodlands with an average temperature of $22.5^{\circ} \mathrm{C}$ in the hot dry season [36]. The highest average annual precipitation falls in the month of January is $191 \mathrm{~mm}$.

\subsection{Methods}

To detect changes in forest cover over a long time span [37-41], Landsat 5 Thematic Mapper (19 June, 1991 and 6 June, 2004) and Landsat 8 Operational Land Imager (25 May, 2017) images were downloaded from the United States Geological Survey website [37]. ArcGIS 10.2 software was used to preprocess (radiometric correction) the images. Preprocessing of satellite images prior to change detection is essential and aims to establish a more direct linkage between the data and biophysical phenomena [42]. The forest cover maps were generated using a maximum likelihood classifier. Owing to an overlap of spectral signatures among classes, land cover was classified into two categories: (1) forest cover, comprising forests and shrubs, and (2) non-forest cover, comprising built-up, grass, and agriculture lands. Roofing materials, such as grass, made it difficult to separate built-up areas from either agriculture or grass land. Before spatial analysis and a temporal comparison, accuracy assessment was performed on each image by randomly selecting 100 sample points. The sample points were then imported into the Google Earth for comparison. The overall accuracy of classification was 96\% for 1991 image, 94\% for 2004 image, and 93\% for 2017 image. The Kappa coefficients of the classification were $0.92,0.88$, and 0.86 for 1991, 2004, and 2017, respectively.

Socioeconomic data on proximate and underlying factors [30] were collected using interviews, focus group discussion, and field observations in August 2017; these methods are used by many researchers in analyzing the factors of deforestation (for example, $[34,43,44])$. Structured interviews were conducted with 399 (256 females, 141 males) heads of households using random sampling technique-66 households were randomly selected in five VDC areas and 69 in one VDC area. 
The sample size was calculated using Cochran's (1963:75) formula [45] below to secure the representativeness of the community:

$$
n=\left(\mathrm{Z}^{2} p(1-p)\right) / e^{2}
$$

where $n$ is the sample size, $Z$ is constant, $e$ is the level of precision, and $p$ is the estimated proportion of an attribute. The purpose of the household survey was to understand socioeconomic conditions, forest dependency, and the awareness of local people regarding forest use and management, i.e., to examine economic and institutional factors as the underlying factors.

Interviews were also conducted with two officers from the Forestry Department and one officer from the Department of Parks and National Wildlife, as well as two members of the Natural Resources Committee (NRC), to identify problems and the current condition of forests in the study area. The focus group discussion was conducted with officers from the Department of Agriculture regarding forest management and challenges. Through the interviews and the focus group discussion, institutional factors as part of the underlying factors were examined.

Field observations were also conducted in the farms and forests during the social surveys in 2017. Photographs were taken to illustrate some of the causes of deforestation in the study area.

Secondary data such as, the prices of tobacco, maize, groundnuts, and soybeans and tobacco farming practices, were collected from the Tobacco Control Commission of Malawi (TCCM), the Agricultural Development and Marketing Corporation (ADMARC), the National Association of Smallholder Farmers (NASFAM), the Labor Office, the Forestry Department, and the reports to analyze the economic factors.

\section{Results}

\subsection{Forest Change Analysis}

The results of the classification show that forest was the dominant land cover in the year 1991 (Figure 2a); however, it has declined tremendously over the years. Forest covered $66 \%$ of the area in 1991 and decreased to $45.8 \%$ in 2017 (Table 1). The annual rate of forest cover loss between 1991 and 2004 was $1.3 \%$ and increased to $1.6 \%$ in the period between 2004 and 2017.
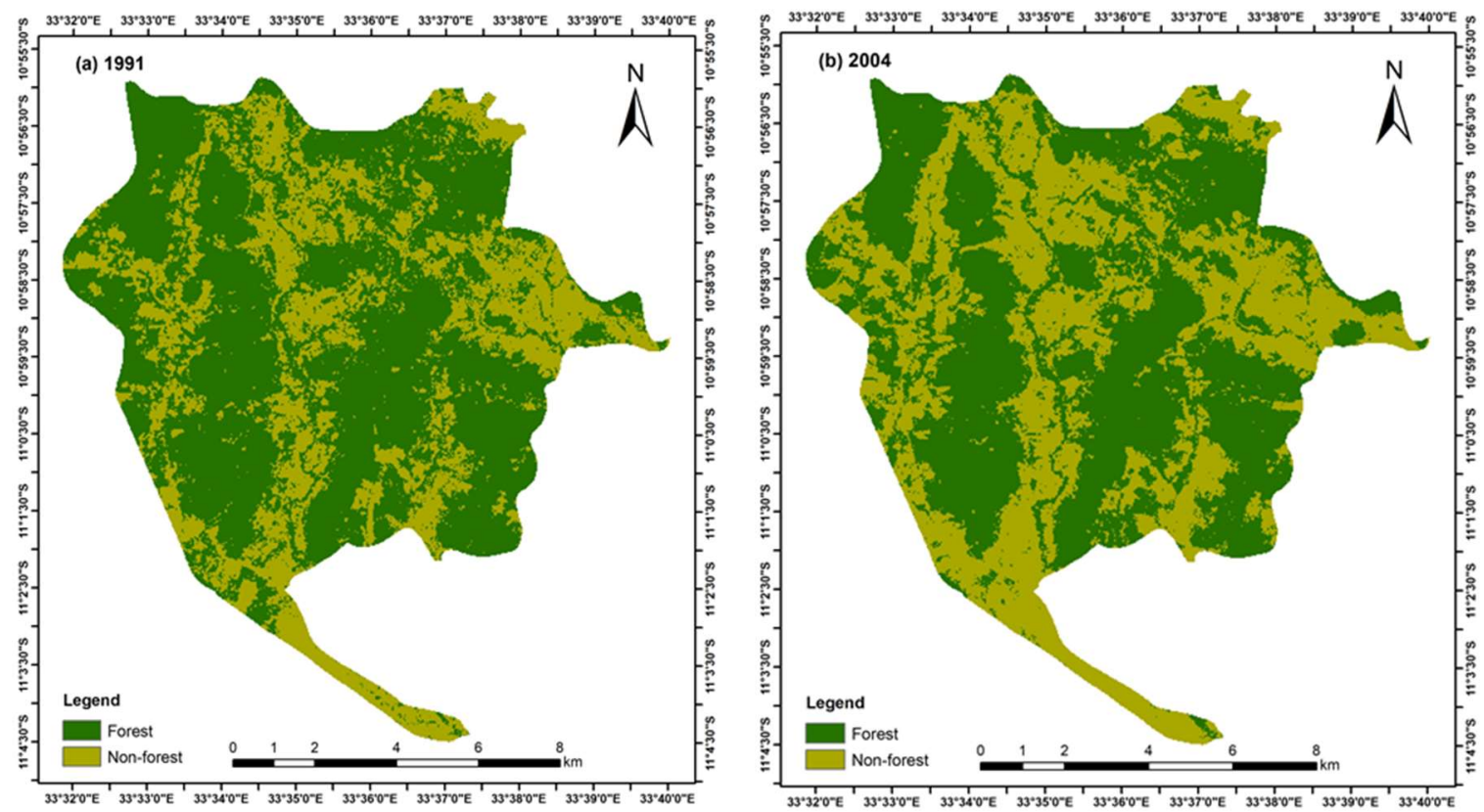

Figure 2. Cont. 


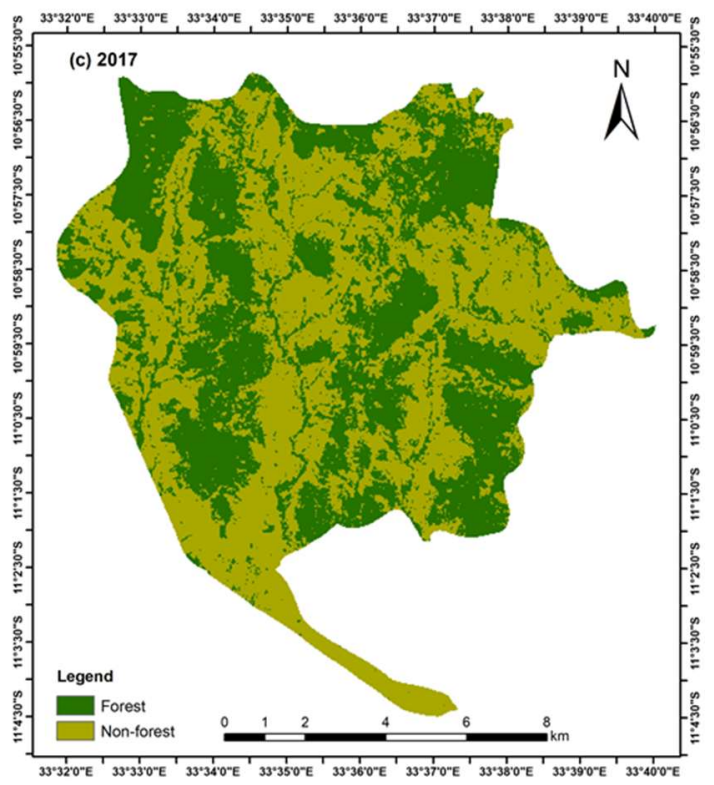

Figure 2. Forest cover maps of Mwazisi in (a) 1991; (b) 2004; and (c) 2017.

Table 1. Change in forest cover from 1991 to 2017.

\begin{tabular}{ccccccc}
\hline \multirow{2}{*}{ Land Cover } & \multicolumn{2}{c}{1991} & \multicolumn{2}{c}{$\mathbf{2 0 0 4}$} & \multicolumn{2}{c}{2017} \\
\cline { 2 - 7 } & Area (ha) & $\mathbf{\%}$ & Area (ha) & $\mathbf{\%}$ & Area (ha) & \% \\
\hline Forest & 7718.76 & 66.0 & 6560.37 & 56.1 & 5364.18 & 45.8 \\
Non-forest & 3983.85 & 34.0 & 5142.24 & 43.9 & 6338.43 & 54.2 \\
\hline Total area & $11,702.61$ & 100.0 & & & \\
\hline
\end{tabular}

\subsection{Drivers of Deforestation}

\subsubsection{Proximate Factors of Deforestation}

Agriculture Expansion

Interviews show that most households $(80.7 \%)$ depend on agriculture to support their daily livelihood while only $19.3 \%$ earn their living through business and employment. All households grow a crop of maize as a staple food, and for the past 15 years, $47.6 \%$ of the households have expanded their maize farm (Figures 3 and 4). On average, each household has expanded its agriculture land by approximately 0.57 hectares during the past 15 years. Most households (91.2\%) expanded their maize farms due to an increase in family size (on average, each household has four children) and a lack of farm inputs. The Pearson product-moment correlation coefficient also shows a positive correlation between the frequency of the agriculture expansion and the number of children in a household (correlation = $\left.0.3764, p=4.949 \times 10^{-6}\right)$.

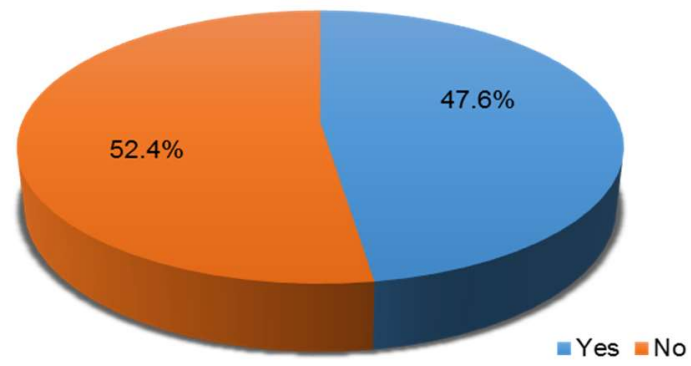

Figure 3. Households that have expanded their agriculture land during the past 15 years $(n=399)$. 


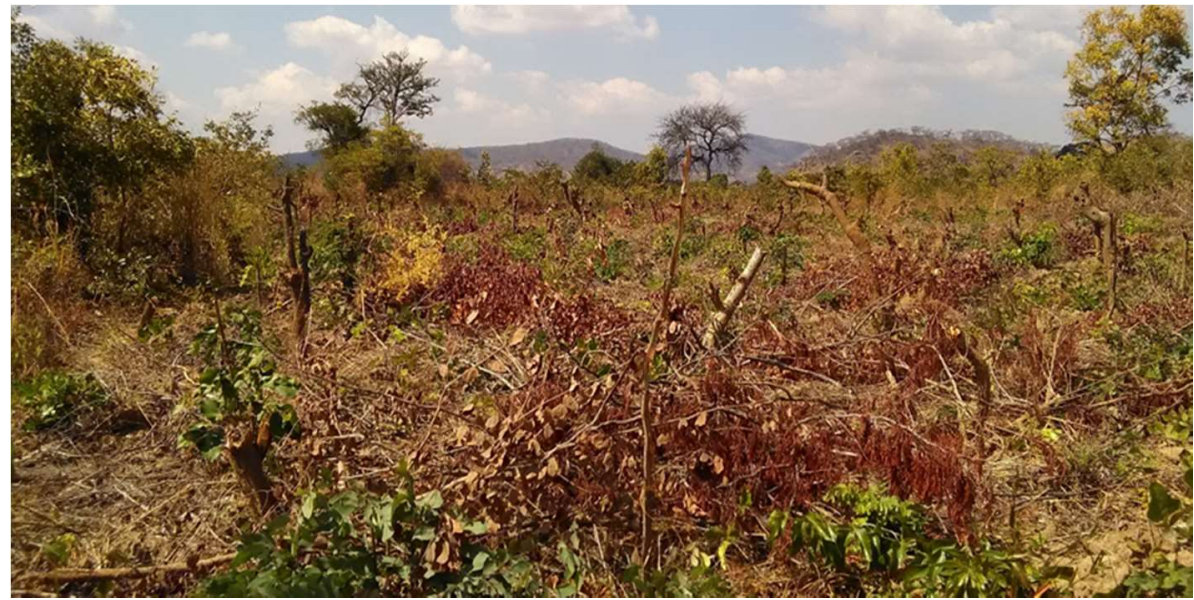

Figure 4. Land being cleared for farming (Photo by Teiji Watanabe, 7 August 2017).

Tobacco Growing

Tobacco is the main cash crop in the area and is grown by $45.4 \%$ of households, while the remaining households depend on subsistence farming. Of the tobacco farmers, $46.4 \%$ expanded their agriculture land by an average of approximately 0.39 hectares per year. These farmers expanded their agriculture land mainly to increase earnings or profit. The type of tobacco grown in the study area is burley, which is air-cured in barns. Figure 5 shows that $69 \%$ of the farmers extracted wood from the forest (including ropes and twigs) to construct the barns (Figure 6).

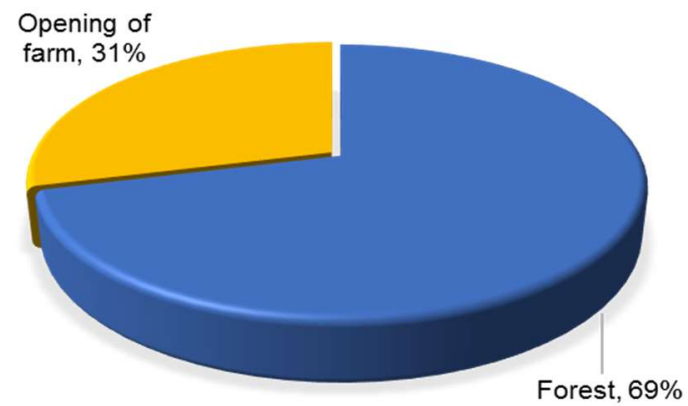

Figure 5. Source of wood for barn construction in Mwazisi $(n=181)$.

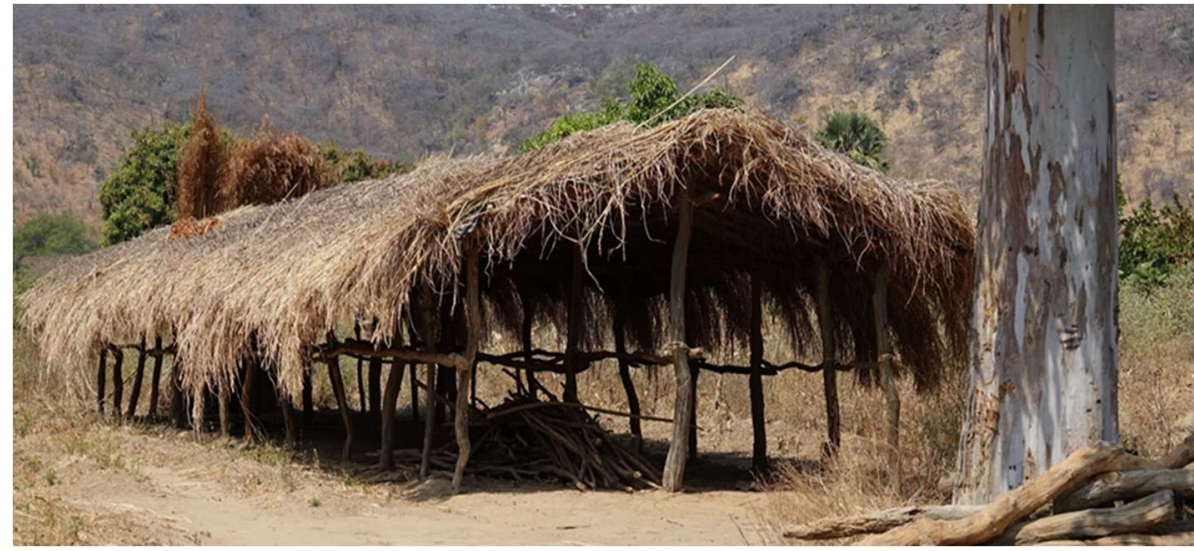

Figure 6. Barn for burley tobacco curing (Photo by Susan Ngwira, 9 August 2017). 


\section{Brick Burning}

There are three types of building materials in Mwazisi: clay bricks, mud, and wood. Clay bricks are the main building material and are used by $65.7 \%$ of the households (Figure 7). Clay bricks are burned before their use in construction and the source of energy is wood (Figure 8). Of the brick-walled houses in the area, $68 \%$ used wood from the forests and $31 \%$ used wood left over after the clearing of land for agriculture. Field results show that each brick-walled house used 4 metric tons of wood, on average.

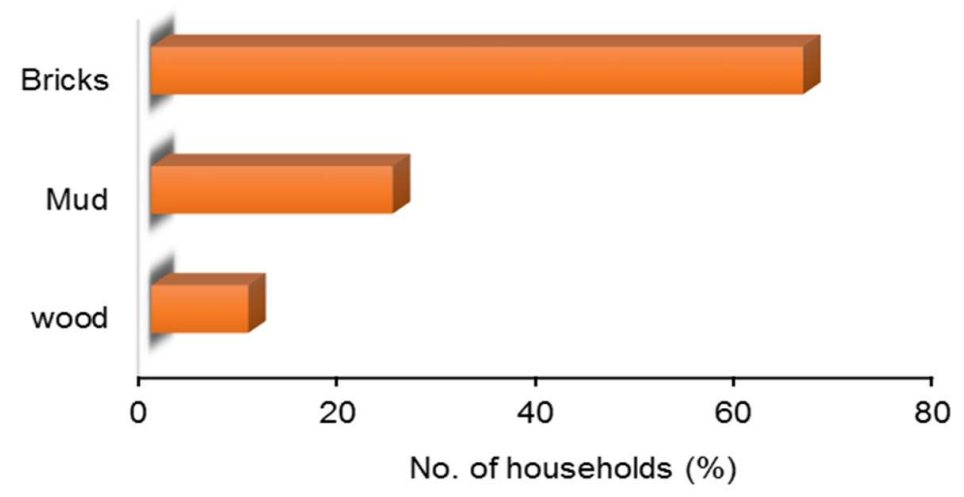

Figure 7. Building materials used in Mwazisi $(n=399)$.

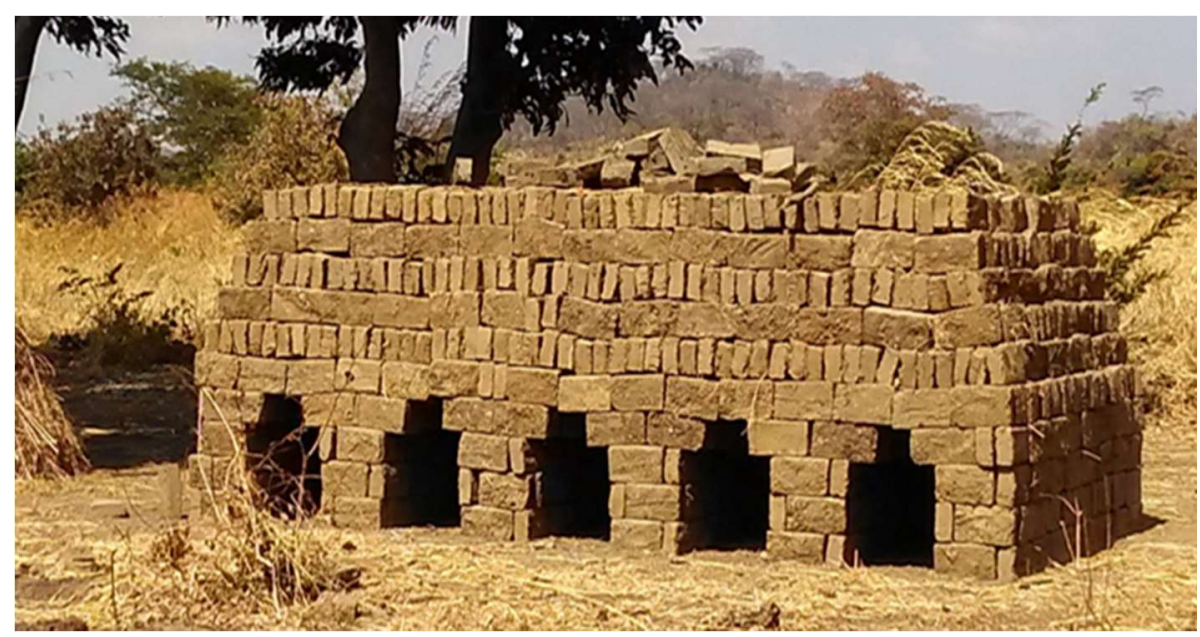

Figure 8. Clay bricks being packed for burning (Photo by Teiji Watanabe, 7 August 2017).

\subsubsection{Underlying Driving Factors}

\section{Economic Factors}

An analysis of the market systems of various crops grown in the area shows that tobacco has a well-developed market structure designed to reach smallholder farmers in the rural areas [5,46-50]. The tobacco crops are sold to international companies based in the capital city of Lilongwe. The tobacco growing is practiced as a form of contract farming, which helps smallholder farmers by providing access to the market, inputs, and extension services [51]. That is, tobacco companies provide loans, expertise, and transportation of the farm produce to the tobacco market. However, it is more expensive and difficult for smallholder farmers to obtain expertise and loans on crops such as ground nuts, maize, and soybeans. This has resulted in an increase in the number of tobacco farmers despite its impact on the forests and environment.

A comparison of the average price of tobacco crop with others grown in the area, such as maize, groundnuts, and soybeans, shows that tobacco has had the highest average price over the years 
(Figure 9a). This motivated $71.3 \%$ of the farmers while the availability of loans and the market motivated $28.8 \%$. However, a comparison of the average yield per hectare per year (Figure $9 \mathrm{~b}$ ) shows that maize has the highest average yield, followed by groundnuts.
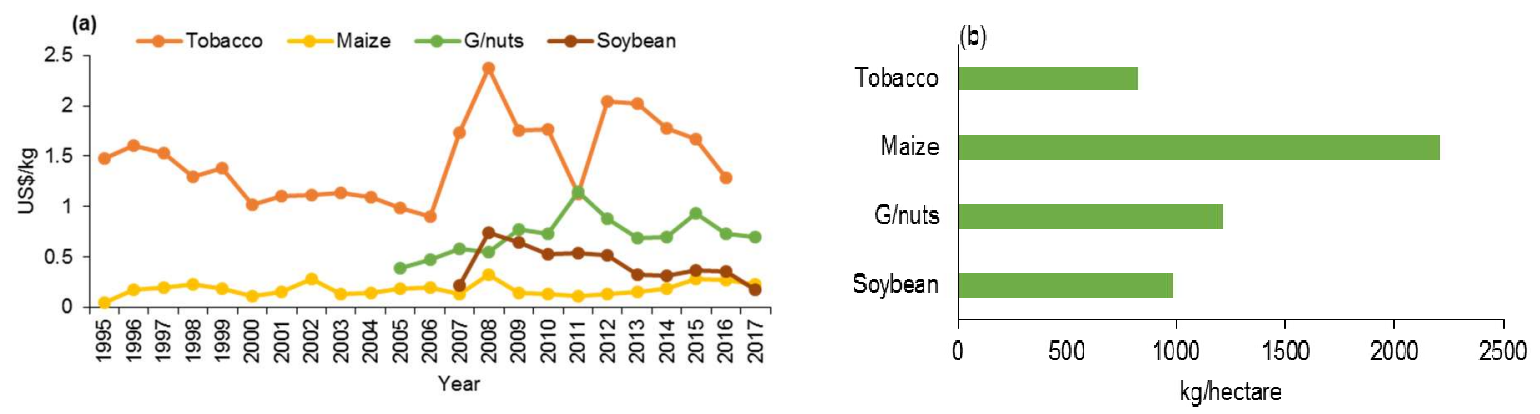

Figure 9. (a) Average annual prices of burley tobacco, maize, G/nuts (groundnuts), and soybeans per kilogram; (b) average yield in kilograms per hectare of soybeans, G/nuts, maize, and tobacco. Data source: TCCM, ADMARC, World Bank, and NASFAM.

Data from the field survey show that $86.1 \%$ of the households in Mwazisi live below the national poverty line ( $<1$ US\$/day) with an average income of approximately $14,151.5 \mathrm{MK} / \mathrm{month}$ (19.84 US\$/month) (Figure 10). Due to poverty, households have failed to purchase farm inputs (to improve soil fertility), which has led to an expansion of cultivation land to increase the harvest yield.

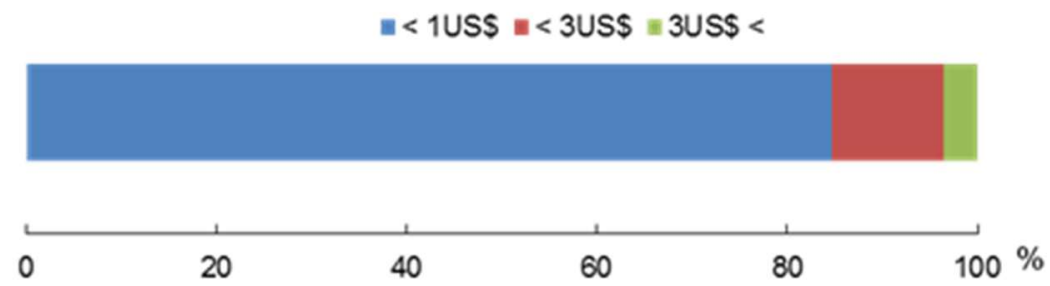

Figure 10. Average monthly income of the families interviewed in Mwazisi $(n=399)$.

The alternative building materials, such as cement (raw material for cement bricks) are regarded as expensive by most households (96.9\%), considering that most of the households live below the national poverty line (Figure 10). The alternative energy sources for brick burning recognized by households $(12 \%)$ in the study area are animal manure, crop remains, and petroleum; however, the interview survey indicated that these households also lack technical knowledge.

\section{Demographic Factors}

There are no population data for the study area; however, there are data for Rumphi (Figure 11). There is an increasing trend in population in the district and an annual population growth rate of Rumphi is 3.4\% [52]. This has resulted in an increase in demand for land for both settlement and agriculture. 


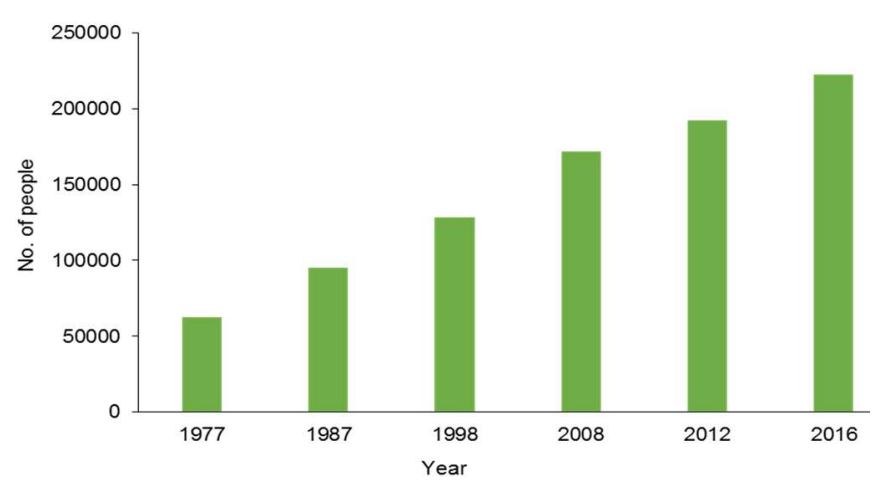

Figure 11. Population of the Rumphi district 1977-2008 and projected population 2012-2016. Data source: National Statistical Office (2016) and IHS4 (2017).

\section{Institutional Factors}

The Forest Act is a fundamental tool for proper forest use and management of private, customary, and public land in Malawi. The results from the field survey, however, show that $95.2 \%$ of households are unfamiliar with the Act. Most households (97.7\%) are unaware of the prohibition of forest wood extraction for brick burning. Furthermore, $97.8 \%$ of tobacco farmers are unaware of the prohibition of forest wood extraction for tobacco processing.

The focus group discussion and interviews with the officers from agriculture and forestry reveal the existence of financial and material constraints in the district. This has led to a reduction in field activities, such as monitoring, awareness campaigns, and law enforcement, especially on customary land forests. With few resources in the district, priority is mostly given to the forest reserves (one gazette and three proposed forest reserves).

Tobacco companies have been involved in deforestation mitigation activities, notably tree planting. However, the initiative has yielded few results. Field survey data show that approximately 10,980 tree seedlings were distributed to tobacco farmers by four tobacco companies in 2016 . The quantity of tree seedlings given to each farmer is determined by the size of the farm (i.e., 130 trees seedlings per 0.5 hectares). Almost all farmers (94\%) planted the seedlings; however, only approximately 257 seedlings survived. The farmers complained about the late distribution of the seedlings (usually distributed towards the end of the rainy season), which resulted in the low survival of the planted seedlings. The focus group discussion and interviews identified that the four tobacco companies do not monitor their farmers while they are planting and caring for the distributed seedlings. Furthermore, there is lack of collaboration between the tobacco companies and governmental departments. That is, the companies rarely share information, resulting in officers' failure to follow up on any activities conducted by the tobacco companies.

\section{Discussion}

\subsection{Interaction between Underlying and Proximate Factors of Deforestion}

This study revealed the existence of multiple underlying driving factors towards the proximate factors of agriculture expansion, tobacco growing, and brick burning. Furthermore, this study identified that each underlying driving factor underpins one or multiple proximate factors, as shown in Figure 12. 


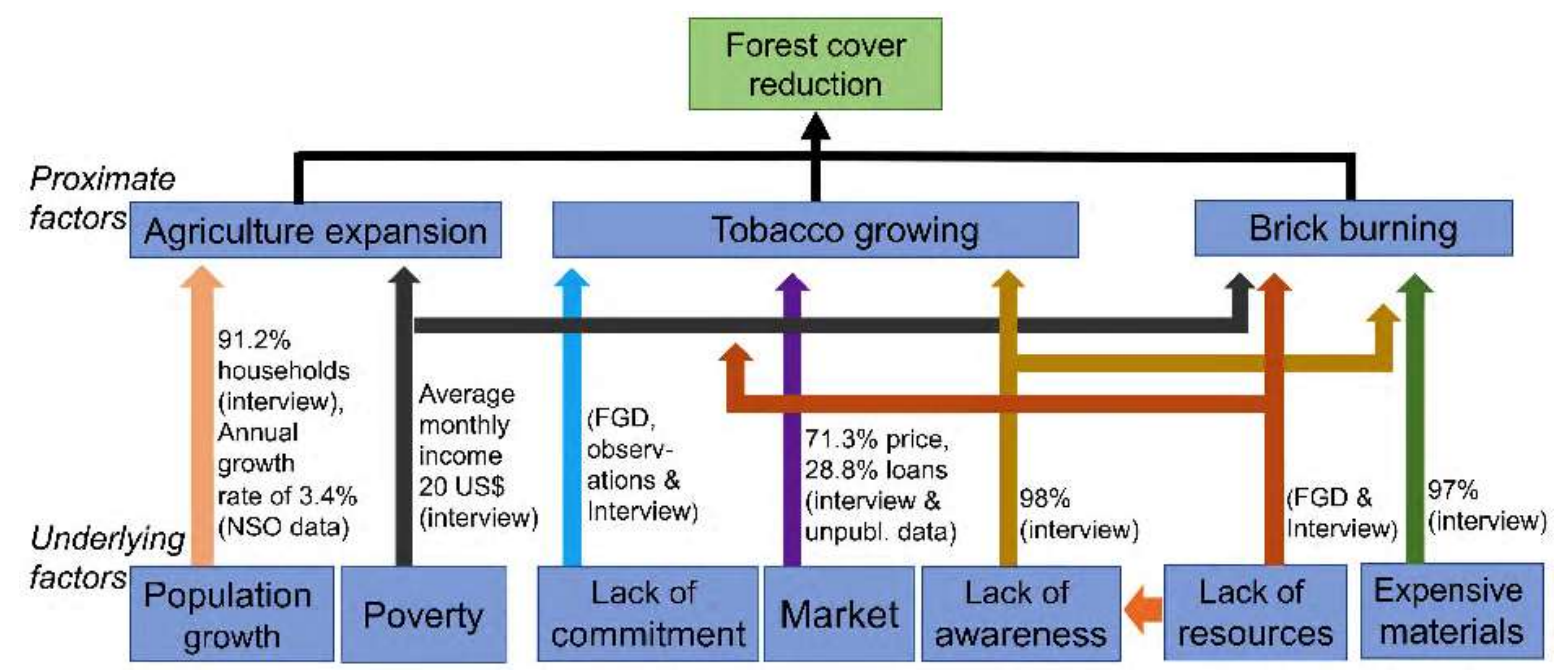

Figure 12. Summary of the interaction between underlying and proximate factors of deforestation in Mwazisi.

An analysis of the satellite images shows a significant areal reduction in the forest cover; it decreased from $66.0 \%$ in 1991 to $45.8 \%$ in 2017 (Table 1). The high rate of the deforestation is partly owing to agriculture expansion, the liberalization of tobacco farming after 1995, and brick burning.

Agriculture supports the livelihood of most households in Mwazisi. Subsistence farming mostly involves crops such as maize, groundnuts, and soybeans (ground nuts and soybeans are usually intercropped with maize). A statistical analysis of the field data showed a positive correlation between the frequency of the agriculture expansion and the number of children in a household (correlation = $0.3764, p$-value $=4.949 \times 10^{-6}$, significance value $=0.05$ ). This finding is in line with the literature, which states that the largest net loss of forest area and large gain in agriculture area (in the low income group of countries) are associated with an increase in the rural population [53] as well as urban population. Nonetheless, agriculture expansion depends not only on an increase in the number of children in a household but also on other factors, such as poverty. Households cannot afford sufficient farm inputs, such as fertilizer, to restore soil fertility, which has further resulted in the expansion of cultivation land to increase the harvest yield. The poverty ratio is higher in rural areas than in urban areas in Malawi-about $43 \%$ of the population in the rural areas reside in poverty, compared with $14 \%$ of the urban population [54]. Most smallholder farmers in the rural areas of Malawi may have little access to fertilizer because of its high price [55].

With regards to the tree planting initiative in tobacco farming, farmers complained about the late distribution of seedlings which affected the survival of the planted seedlings. A study by Clarkson [56] showed that many farmers would devote their resources to planting trees if they were able to source seedlings at an appropriate time in the year. Appropriate timing for seed distribution and monitoring would help to increase the survival rate of the planted tree seedlings as the interviewees accounted for. Also, the tobacco companies demonstrate a lack of commitment. The tobacco companies do not monitor farmers when they are planting and managing the care of the distributed tree seedlings. In 2016, among approximately 10,980 tree seedlings distributed, 257 seedlings were alive, as described earlier. These findings are similar to the results obtained by the Extension Service of Malawi, which found that $80 \%$ of the estate farmers had failed to follow the government's recommendation to plant trees on $10 \%$ of the farm land [11]. The tobacco companies are much more interested in the economic benefits of tobacco and pay little attention to the forest degradation caused by tobacco [11]. Currently, tobacco farmers meet their wood needs with trees from the forests nearby-burley tobacco requires 158 trees for every 0.15 hectares of tobacco [57].

Bricks are the main building materials in both urban and rural settings in Malawi, and the wood needed for brick production is extracted from natural woodlands or forests. The alternative building 
materials, such as cement, are regarded as expensive, especially for rural residents, because most households live below the national poverty line (Figure 10). When comparing the clay bricks produced in an open kiln with those produced by an alternative method called Vertical Shaft Brick Kiln (VSBK or Eco-kiln), which consumes less fuel and also uses carbonaceous waste or coal, the price of each VSBK brick is three times more expensive than that of bricks produced in an open kiln [58]. Consequently, people opt for the cheaper bricks. The VSBK method also requires a huge amount of capital for its establishment and it mostly targets the urban population, which only constitutes $14.39 \%$ of households, compared to households in the rural areas of the northern region, which comprise $86.61 \%[52,58]$.

\subsection{Deforestation on Customary Land}

The majority of users of wood energy are found in the customary land in rural areas, where almost $90 \%$ of the population lives [52]. According to the literature [59] over 50\% of the wood energy in Malawi comes from customary forests and woodlands. Forests on customary land are managed by the rural community; therefore, proper knowledge, support, and empowerment are required, although they are imbalanced between the rural and urban areas. According to Sillah [60], the awareness level of the local population concerning conservation and rational utilization of forest resources must be augmented to acquire the active participation and commitment of communities and individuals. The findings of this study, however, show a low level of awareness among those in the local population regarding forest use and management. The lack of resources at the district level has partly contributed to the problem. For example, the forestry budget for one year (2016-2017) for Rumphi was 9366.87 US\$ with a monthly budget of 780.57 US $\$$. This has resulted in a reduction in law enforcement, awareness campaigns, and monitoring, especially for customary land forests as the interviewees accounted for. Developing countries barely meet the financial, material, and personnel requirements for sustainable forest management. People continue to illegally extract wood from customary land forests for either commercial or non-commercial purposes.

\subsection{Measures to Mitigate Pressure on Forests}

Tobacco is an important cash crop in Malawi, as it accounts for 35\% of the Gross Domestic Product [3]. The results of this study suggest the existence of a number of factors that motivate farmers to grow tobacco over other cash crops, which include: (1) the availability of loans facilitated by the tobacco companies, (2) a better price for tobacco compared to that of other cash crops, and (3) easy access to tobacco information and the availability of a market for the crop. These results are similar to those of the research conducted by the Centre for Agricultural Research and Development [61]. Hall [53] reported that most governments send out mixed messages regarding their concern for people and the environment, while actively and assiduously promoting the very economic sectors that drive deforestation. If the supply chains for alternative crops were developed to the level of tobacco supply chains, the prices and profitability of these crops would also grow and eclipse those of contract tobacco [56]. This, in turn, would help to reduce the pressure on forest resources exerted by tobacco farming.

The alternative for brick burning in the study area would be an introduction of stabilized soil bricks (SSBs) $[16,62]$ and promotion of its use. This method involves the use of either soil alone or a mixture of soil and a minimum amount of $10 \%$ cement. The mixed soil and cement are compressed at high pressure and are cured under a shade [16]. This method produces bricks using very little or no energy; therefore, this alternative would lead to reduction of deforestation.

\subsection{Limitation of the Study}

Although this study found a decrease in forest cover, higher spatial resolution images would be able to separate overlapping classes, such as forest and shrubs, and built-up grass and agriculture lands, more accurately. The results of the social survey may be applied to some local areas in the country, 
but an accumulation of similar studies is necessary to understand the similarities and differences among its local levels.

\section{Conclusions}

Landsat images were used to assess forest cover changes of the study area. Forest cover in Mwazisi was reduced from 66\% in 1991 to 45.8\% in 2017. Qualitative and quantitative methods were used to assess socioeconomic conditions, forest dependency, and the underlying driving factors of deforestation. Households continue to depend on forest resources for (1) agriculture expansion, (2) tobacco curing, and (3) brick burning. The underlying factors towards these anthropogenic factors are the market system, poverty, and population growth, expensive alternative building materials, lack of awareness, lack of resources, and lack of commitment. Each of these underlying drivers of deforestation interacts with single or multiple proximate factors. Additionally, there are multiple underlying driving factors working together to underpin each proximate factor of deforestation, thereby impacting the forest cover reduction in Mwazisi. Synergies also exist between some underlying driving factors, such as a lack of awareness and resources. A set of economic, institutional, and demographic factors underpin agriculture expansion, tobacco growing, and brick burning in Mwazisi, Malawi. The following recommendations would facilitate the reduction in the deforestation rate: Providing technical support to the village heads and Community-Based Natural Resources Management Committee on forest management, and monitoring the tobacco companies operating in the district.

Author Contributions: Conceptualization, S.N. and T.W.; methodology, S.N. and T.W.; validation, S.N. and T.W.; investigation, S.N. and T.W.; writing-original draft preparation, S.N.; writing-review and editing, S.N. and T.W.; visualization, S.N. and T.W.; supervision, T.W.; funding acquisition, S.N. and T.W.

Funding: This research was partially funded by the Japan International Corporation Agency (JICA).

Acknowledgments: We are grateful to the Japan International Cooperation Agency (JICA) and the Japan International Cooperation Centre (JICE) for the scholarship (African Business Education Initiative (D-16-05395)) to S.N. and the funding for fieldwork during this research.

Conflicts of Interest: The authors declare no conflict of interest.

\section{References}

1. Arekhi, S. Modeling spatial pattern of deforestation using GIS and logistic regression: A case study of northern Ilam forests, Ilam province, Iran. Afr. J. Biotechnol. 2011, 10, 16236-16249. [CrossRef]

2. Tejaswe, G. Mannual on Deforestation, Degradation, and Fragmentation Using Remote Sensing and GIS. Strengthening Monitoring, Assessment and Reporting on Sustainable Forest Management in Asia (GCP/INT/988/JPN); MAR-SFM Working Paper 5; FAO: Rome, Italy, 2007; Available online: http:/ /www.fao. org/forestry / mar/53839/en/ (accessed on 12 September 2018).

3. Mauambeta, D.; Chitedze, D.; Mumba, R. Status of Forests and Tree Management in Malawi; Coordination Union for Rehabilitation of the Environment (CURE): Lilongwe, Malawi, 2010.

4. Gowela, J.; Masamba, C. State of Forest and Tree Genetic Resources in Malawi; Working Paper FGR/27E; FAO: Rome, Italy, 2002.

5. Kambewa, P.; Chiwaula, L. Biomass Energy Use in Malawi; International Institute for Environment and Development (IIED): London, UK, 2010.

6. Taulo, J.L.; Gondwe, K.J.; Sebitosi, A. Energy supply in Malawi: Options and issues. J. Energy S. Afr. 2015, 26, 19-32. [CrossRef]

7. FAO. Review of Food and Agricultural Policies in Malawi; Country Report 2014; FAO: Rome, Itally, 2015.

8. Forests and the Forestry Sector: Malawi. Available online: http:/ /www.fao.org/forestry/country/57478/ en/mwi/ (accessed on 5 August 2018).

9. Pullanikkatil, D.; Palamuleni, L.; Ruhiiga, T. Assessment of land use change in Likangala river catchment, Malawi: A remote sensing and DPSIR approach. Appl. Geogr. 2016, 71, 9-23. [CrossRef]

10. Government of Malawi. Biomass Energy Strategy; Government of Malawi: Lilongwe, Malawi, 2009. 
11. The World Bank. World Development Indicators; The World Bank: Washington, DC, USA, 2011.

12. The World Bank. Malawi Economic Monitor: Harnessing the Urban Economy, Mulanje House; World Bank Office: Lilongwe, Malawi, 2017.

13. Lee, K.; Batero, N.C.; Novotny, T. “Manage and mitigate punitive regulatory measures, enhance the corporate image, influence public policy": Industry efforts to shape understanding of tobacco-attributable deforestation. Glob. Health 2016. [CrossRef] [PubMed]

14. Wiyo, K.A.; Fiwa, L.; Mwase, W. Solving deforestation, protecting and managing key water catchments in Malawi using smart public and private partnerships. J. Sustain. Dev. 2015, 8, 251-261. [CrossRef]

15. Zingano, B.W. The Problem of Fuel Wood Energy Demand in Malawi with Reference to the Construction Industry; Zingano and Associates: Lilongwe, Malawi, 2005.

16. Johnson, X.F.; Jumbe, C. Policy: Energy Access and Biomass Resource Transitions in Malawi; Stockholm Environmental Institute: Stockholm, Sweden, 2013.

17. Malawi Land Act 2016. Available online: https://malawilii.org/mw/legislation/act/2016/16 (accessed on 21 February 2019).

18. Malawi Customary Land act 2016. Available online: https://malawilii.org/mw/legislation/act/2016/19 (accessed on 21 February 2019).

19. The Program on Governance and Local Development. The Local Governance Perfomance Index (LGPI) in Malawi: Selected Findings on Land; The Report Series 2016:4; Institute of Public Opinion and Research, University of Gothernburg: Gothenburg, Sweden; Available online: https://gld.gu.se/media/1256/report-lgpi-landmalawi.pdf (accessed on 1 February 2019).

20. Pandey, A.K.; Tripathi, Y.C.; Kumar, A. Non timber forest products (NTFPs) for sustainable livelihood: Challenges and strategies. Res. J. For. 2016, 10, 1-7. [CrossRef]

21. Ntupanyama, Y.; Mughogho, N. Forests, Rangelands and Climate Change Adaptation in Malawi, Africa. A presentation Made in Johannesburg on 17 June 2013. Available online: $\quad$ https: / / www.google.com.hk/url?sa=t\&rct=j\&q=\&esrc=s\&source=web\&cd=1\&ved= 2ahUKEwizhYzT3fngAhWbwIsBHcrFDHQQFjAAegQIAhAC\&url=http\%3A\%2F\%2Fwww. fao.org\%2Fforestry\%2F38069-073886f44b766b8982dec68ac4c3a784a.pdf\&usg=AOvVaw0Rd6XUJEuk6mZNOfO76hQ (accessed on 15 December 2018).

22. Kamanga, P.; Vedeld, P.; Sjaastad, E. Forest incomes and rural livelihoods in Chiradzulu district, Malawi. Ecol. Econ. 2009, 68, 613-624. [CrossRef]

23. Hansen, J.D.; Luckert, M.K.; Minae, S.; Place, F. Tree planting under customary tenure systems in malawi: Impacts of marriage and inheritance patterns. Agric. Syst. 2005, 84, 99-118. [CrossRef]

24. FAO. Forests, Trees and People Programme; Forestry Department, Working Paper No. 3; FAO: Rome, Italy, 2000; Available online: http:/ /www.fao.org/docrep/006/x2104e/X2104E00.HTM\#TopOfPage (accessed on 2 January 2018).

25. Twongyirwe, R.; Bithell, M.; Richards, K.S. Revisiting the drivers of deforestation in the tropics: Insights from local and key informant perceptions in western Uganda. J. Rural Stud. 2018, 63, 105-119. [CrossRef]

26. Katumbi, N.; Nyengere, J.; Mkandawire, E. Drivers of deforestation and forest degradation in Dzalanyama forest reserve in Malawi. Int. J. Sci. Res. 2015, 6, 889-893.

27. Mandondo, A.; German, L.; Utila, H. Assessing societal benefits and trade-offs of tobacco in miombo woodlands of Malawi. Hum. Ecol. 2014, 42, 1-19. [CrossRef]

28. Kerr, A. Disapearing Forests in Malawi: Causes and Solutions; EEP 153 Research Project; EEP: Santa Clara, CA, USA, 2015.

29. Otsuka, K.; Place, F. Land tenure, and natural resource management: The case of customary land area in Malawi. J. Environ. Econ. Manag. 2001, 41, 13-32. [CrossRef]

30. Geist, H.L.; Lambin, E.F. Proximate causes and underlying driving forces of tropical deforestation. BioScience 2002, 52, 143-150. [CrossRef]

31. Bürgi, M.; Hersperger, A.M.; Schneeberger, N. Driving forces odf landscpae change-Current and new directions. Landsc. Ecol. 2004, 19, 857-868. [CrossRef]

32. Nelson, G.C.; Bennett, E.; Berhe, A.A.; Cassman, K.; DeFries, R.; Dietz, T.; Dobermann, A.; Dobson, A.; Janetos, A.; Levy, M.; et al. Anthropogenic drivers of ecosystem change: An overview. Ecol. Soc. 2006, 11, 29. [CrossRef] 
33. Roy Chowdhury, R. Driving forces of tropical deforestation: The role of remote sensing and spatial models. Singap. J. Trop. Geogr. 2006, 27, 82-101. [CrossRef]

34. Roy, S.; Islam, M.S.; Islam, M.M. Underlying causes of deforestation and its effects on the environment of Madhupur sal forest, Bangladesh. Bangladesh J. Sci. 2014, 27, 162-169.

35. Lim, C.L.; Prescott, G.W.; De Alban, J.D.T.; Ziegler, A.D.; Webb, E.L. Untangling the proximate causes and underlying drivers of deforestation and forest degradation in Myanmar. Conserv. Biol. 2017, 31, 1362-1372. [CrossRef] [PubMed]

36. Climate-Data.org. Available online: https://en.climate-data.org/africa/malawi/northern/rumphi-27935/ (accessed on 25 November 2018).

37. United States Geological Survey. Available online: www.earthexplorer.usgs.gov (accessed on 10 January 2018).

38. Wulder, M.A.; White, J.C.; Goward, S.N.; Masek, J.G.; Irons, J.R.; Herold, M. Landsat continuity: Issues and opportunities for land cover monitoring. Remote Sens. Environ. 2008, 112, 955-969. [CrossRef]

39. Afify, H.A. Evaluation of change detection techniques for monitoring land-cover changes: A case study in new Burg El-Arab area. Alexandria Eng. J. 2011, 50, 187-195. [CrossRef]

40. Andualem, T.G.; Belay, G.; Guadie, A. Land use change detection using remote sensing technology. J. Earth Sci. Clim. Chang. 2018, 9, 1-6. [CrossRef]

41. Abd El-Kawy, O.R.; Rød, J.K.; Ismail, H.A.; Suliman, A.S. Land use and land cover change detection in the western Nile delta of Egypt using remote sensing data. Appl. Geogr. 2011, 31, 483-494. [CrossRef]

42. Chander, G.; Markham, B.L.; Helder, D.L. Summary of current radiometric calibration coefficients for Landsat MSS, TM, ETM+, and EO-1 ALI sensors. Remote Sens. Environ. 2009, 113, 893-903. [CrossRef]

43. Makunga, J.E.; Misana, S.B. The extent and drivers of deforestation and forest degradation in Masito-Ugalla ecosystem, Kigoma region, Tanzania. Open J. For. 2017, 7, 285-305. [CrossRef]

44. Anyanwu, J.C.; Nwobu, E.A.; Osuiwu, B.O. Analysis of factors responsible for deforestation in Anambra state of Nigeria. IOSR J. Environ. Sci. Toxicol. Food Technol. 2013, 5, 23-31.

45. Israel, G.D. Determining Sample Size; Agricultural Education and Communication Department, UF/IFAS Extension, University of Florida: Gainesville, FL, USA, 1992.

46. Thindwa, M.O.; Seshamani, V. Trade liberalization and the performance of the tobacco sector in Malawi. J. Emerg. Issues Econ. Financ. Bank. 2014, 3, 962-975.

47. FAO. Analysis of Price Incentives for Groundnuts in Malawi 2005-2013; Technical Notes Series, MAFAP; FAO: Rome, Italy, 2014.

48. FAO. Analysis of Price Incentives for Maize in Malawi 2005-2013; Technical Note Serie, MAFAP; FAO: Rome, Italy, 2014.

49. Minot, N. Staple food prices in Malawi. In Proceedings of the COMESA Policy Seminar on "variation in Staple Food Prices: Causes, Consequences and Policy Options", under the African Agricultural Marketing Project (AAMP), Maputo, Mozambique, 25-26 January 2010.

50. Giertz, A.; Caballero, J.; Galperin, D.; Makoka, D.; Olson, J.; German, G. Malawi Agricultural Sector Risk Assessment; Agriculture Global Practice Technical Assistance Paper; World Bank Group Report Number 99941-MW; The World Bank: Washington, DC, USA, 2015.

51. Kumwenda, I.; Madola, M. The Status of Contract Farming in Malawi; Food, Agriculture and Natural Resources Policy: Rome, Italy, 2005.

52. National Statistical Office. Malawi 2016 Statistical Yearbook. Available online: www.nsomalawi.mw (accessed on 28 April 2018).

53. Hall, R. (Ed.) REDD + and the Underlying Causes of Deforestation and Forest Degradation; Global Forest Coalition: Asuncion, Paraguay, 2013.

54. Vandemoortele, M.; Bird, K. Progress in Economic Conditions; A Recent Example of Progress in Malawi; Development Progress, Overseas Development Institute: London, UK, 2011.

55. FAO. The State of World's Forest Genetic Resources; Country report; FAO: Rome, Italy, 2013.

56. Clarkson, G. On farm tree planting in Malawi. Agric. Dev. 2012, 16, 29-32.

57. Bunderson, W.T.; Hayes, I.M. Sustainable tobacco production in Malawi: The role of wood demand and supply. In Proceedings of the Seminar on Malawi Tobacco and the Future, Lilongwe, Malawi, 4-5 October 1997. 
58. Scalable Solutions for People and Our Planet: VSBK Malawi Project Summary. Available online: https: / / www.tara.in/malawi.aspx (accessed on 3 June 2018).

59. Kainja, S.; Bekele, M. (Eds.) Forest outlook studies in Africa (FOSA); Forest Products Society: Lilongwe, Malawi, 2001.

60. Sillah, J.S. Underlying Causes of Deforestation and Forest Degradation: The Republic of Gambia. Available online: http:/ / www.wrm.org.uy/oldsite/deforestation/Africa/gambia.html (accessed on 17 August 2017).

61. Drope, J.; Makoka, D.; Lencucha, R.; Appau, A. Farm-Level Economics of Tobacco Production in Malawi; A Reviesd Report; Centre for Agricultural Research and Development (CARD), Lilongwe University of Agriculture and Natural Resources (LUANAR): Lilongwe, Malawi, 2016.

62. Eires, R.; Sturm, T.; Camoes, A.; Ramos, L.F.; Study of New Interlocking Stabilized Compressed Earth Masonry Block. Research in Material and Technology for Conservation and Contemporary Architecture. 2014. Available online: https:/ /www.researchgate.net/publication/264119160_Study_of_a_new_interlocking_ stabilised_compressed_earth_blocks (accessed on 22 February 2019).

(C) 2019 by the authors. Licensee MDPI, Basel, Switzerland. This article is an open access article distributed under the terms and conditions of the Creative Commons Attribution (CC BY) license (http:// creativecommons.org/licenses/by/4.0/). 